assay in these patients, especially if they are postmenopausal?

P D DAWKINS

G R SPENCER

Musgrove Park Hospital,
Taunton, Somerset TAl 5DA

Hawkins RA, Roberts MM, Forrest APM. Br f Surg 1980;67:153-67.

** We sent this letter to the authors, who reply in the two letters below.-ED, BMF.

SIR,-It is evident that conflicting information exists in the literature relating oestrogenreceptor status to tumour histological grade. ${ }^{12}$

In our series of 414 cancers 252 were graded by one independent pathologist, who used the criteria for grading described by Bloom and Richardson. ${ }^{3}$ Although there was a tendency for oestrogen-receptor-positive tumours to be better differentiated than receptor-negative ones, there was no significant association between receptor status and histological grade, as the accompanying table shows. The distribution of tumours by grade in this series is almost identical with that described by Bloom and Richardson ${ }^{3}(26 \%$ grade I, $45 \%$ grade II, and $29 \%$ grade III).

Histological grade and oestrogen receptor status in 252 cancers of the breast

\begin{tabular}{|c|c|c|c|}
\hline $\begin{array}{l}\text { Oestrogen-receptor } \\
\text { status }\end{array}$ & Grade I & Grade II & Grade III \\
\hline $\begin{array}{l}\text { Positive ... } \\
\text { Negative ... }\end{array}$ & $\begin{array}{l}35 \\
27\end{array}$ & $\begin{array}{l}47 \\
53\end{array}$ & $\begin{array}{l}34 \\
42\end{array}$ \\
\hline Total & $62\left(26^{\circ}\right)$ & 6) $100(42 \%$ & o) $76(32 \%$ \\
\hline
\end{tabular}

Of the 252 tumours, 37 were Bloom grade I and also node negative. In this small subgroup those patients with oestrogen-receptor-positive grade I tumours appear to have a more favourable prognosis than those with oestrogenreceptor-negative grade I tumours. Life table analysis shows that in the group of 22 patients who were lymph-node negative and oestrogenreceptor positive, $100 \%$ were disease free at 60 months, whereas in the 15 who were node negative and receptor negative only $55 \%$ were disease free. (Survival figures are not given since too few events have occurred to allow meaningful assessment.)

While we accept that tumour grade is a useful prognostic factor, histological grading is inevitably subjective; and this may well explain the discrepancies that exist between the results of different centres. By contrast, oestrogen-receptor analysis is a more objective measurement, and in our hands is independent of tumour grade based on the criteria described by Bloom and Richardson. This finding has perhaps the advantage that both tumour grade and oestrogen-receptor status can be combined to provide a more accurate prediction of prognosis than either factor used on its own.

R CROTON STEPHEN HOLT

University Department of Surgery

I MCDICKEN

University Department of Pathology, Royal Liverpool Hospital,

W D GEORGE

University Department of Surgery, Western Infirmary,
Glasgow G11 6NT
KeITH GRIfFITHS

R I NicHOLSON

Tenovus Institute for Cancer Research,

Welsh National School of Medicine, Cardiff CF4 4XX

' Rosen PP, Menendez-Botet CJ, Nisselbaum JS. Cancer Res 1975;35:3187.

2 Maynard PV, Davies CJ, Blamey RW, Elston CW, Johnston J, Griffiths K. Br f Cancer 1978;38:745-8 Bloom HJG, Richardson WW. Br $\mathcal{F}$ Cancer 1957; 11:
359-77.

SIR,-It is unfortunate that in our study of patients with early breast cancer there was no clear relationship between tumour histological grade and oestrogen-receptor content, and it is unlikely therefore that at this particular medical centre tumour grade would provide a more effective prognostic parameter than oestrogen-receptor status.

In contrast to the Liverpool data, a major study involving the Tenovus Institute and Professor Roger Blamey, City Hospital, Nottingham, demonstrated a close correlation between tumour histological grade and oestrogen-receptor status. Over $70 \%$ of the grade I tumours studied in this series, assessed on the Bloom and Richardson scale by $\mathrm{Dr}$ Chris Elston, were found to be oestrogenreceptor positive and patients with these tumours had an extremely favourable prognosis. Moreover, a large proportion of the grade III tumours were oestrogen-receptor negative. ${ }^{1}$ Many reports from other groups around the world have subsequently confirmed this relationship between oestrogen-receptor status and the degree of tumour differentiation Clearly, where an expert, experienced breast pathology service exists tumour grade is a valuable prognostic factor; but it must be accepted that measurement of oestrogenreceptor content of breast tumour samples by a specialist laboratory offers the more objective parameter as a guide to the identification of patients at high or low risk. It is also relevant that further data from the NottinghamTenovus study suggests that the oestrogenreceptor content of primary breast tumours is a more accurate means of predicting the subsequent response to endocrine therapy of the patients who eventually present with recurrent disease than is tumour grade, and also correlates better with the site of metastatic disease.

The available evidence, therefore, indicates the importance of oestrogen-receptor status as a prognostic indicator. ${ }^{2}$ It must be appreciated however, that in this most complex disease all available clinical and biochemical factors should be considered when one is assessing prognosis or selecting patients for therapy.

K GRIFFITHS

Tenovus Institute for

Cancer Research,
Welsh National School of Medicine,

${ }^{1}$ Elston CW, Blamey RW, Johnson J, Bishop HM Haybittle JL, Griffiths K. In: Mouridsen HT Palshof T, eds. Breast Cancer-experimental and clinical

2 Nicholson RI, Campbell SC, Blamey RW, Elston DW, George D, Griffith K. $\mathcal{F}$ Steroid Biochem 1981

\section{Diagnosis and treatment of} lactose intolerance

SIR,-I have read Dr Anne Ferguson's leading article (28 November, p 1423) on this subject with interest. May I, however, register a mild protest on one small point? Dr Ferguson apparently attributes the persistence of lactase in adult life in Europeans and North Africans and its cessation after early childhood in many Asiatics and Negroes to genetic differences. How is the gene mutation responsible for persistence to be visualised? Did it take place in a large number of individuals more or less simultaneously or in a single remote ancestor? In the latter case the ancestor in question could not have been very far removed from Adam and Eve.

Indications are that the change to lactose tolerance in adults is of multicentric origin. Man has colonised many inhospitable habitats with little if any vegetation suitable for human consumption. Under such conditions he had to become either a hunter or a herdsman, in the latter case usually living on both the meat and the milk of his animals. Such conditions arose in such widely separated parts of the earth as central Asia, some parts of Africa, and Antarctica. In all such cases tribesmen as different as the Khirgiz, the Masaai, and the Lapps must have acquired the ability of digesting milk in adult life. There is a strangely Lamarckian flavour about lactose tolerance: it is acquired when needed, abandoned when not needed.

Apart from deserts, semi-deserts, and similar habitats, lactose tolerance probably has a negative survival value. Why should tissues be maintained throughout life when, under natural conditions, they are needed only in infancy ? Apart from that, many of us suspect that milk is atherogenic. In a recent epidemiological survey ${ }^{\mathbf{2}}$ I have found strong correlation between the consumption of unfermented milk proteins and mortality from coronary disease. For instance, the highest known consumption rate of such proteins, in Finland, coincides with the highest known male mortality from heart disease. In Germany, Yugoslavia, and Japan, where the consumption of unfermented milk proteins is approximately a half, a quarter, and a tenth of that in Finland, male coronary mortality is also approximately a half, a quarter, and a tenth of the Finnish rate. To give another example, negative correlation between lactose intolerance and coronary mortality was reported by Segall. ${ }^{3}$

While one sympathises with the plight of the lactose intolerant in a milk-addicted society, the condition may have its compensations. I could go so far as to suggest that perhaps it is not they who should fall in step with us. It might be better if we fell in step with them.

STEPHEN SEELY

Sale, Cheshire M33 5DF

1 Seely S. Med Hypoth $1981 ; 7: 907-18$

${ }^{3}$ Segall JJ. Intern $\mathcal{f}$ Epidemiol $1981 ; 9: 271-5$.

Changes in glycosylated haemoglobin after oral glucose load

SIR,-We read with interest the paper by Dr I N Scobie and others (3 October, p 877) describing changes in glycosylated haemoglobin $\left(\mathrm{HbA}_{1}\right)$ up to 30 days after an oral glucose tolerance test. While $\mathrm{HbA}_{1}$ values remained unchanged during the test the authors noted a significant increase of $\mathrm{HbA}_{1}$ 10-30 days after the test.

We would like to report our own observations during and after continuous glucose infusion. After an overnight fast we administered $1.0 \mathrm{~g} / \mathrm{h}$ glucose per $\mathrm{kg}$ body weight to 10 healthy volunteers for six hours. Blood glucose and the total fraction 


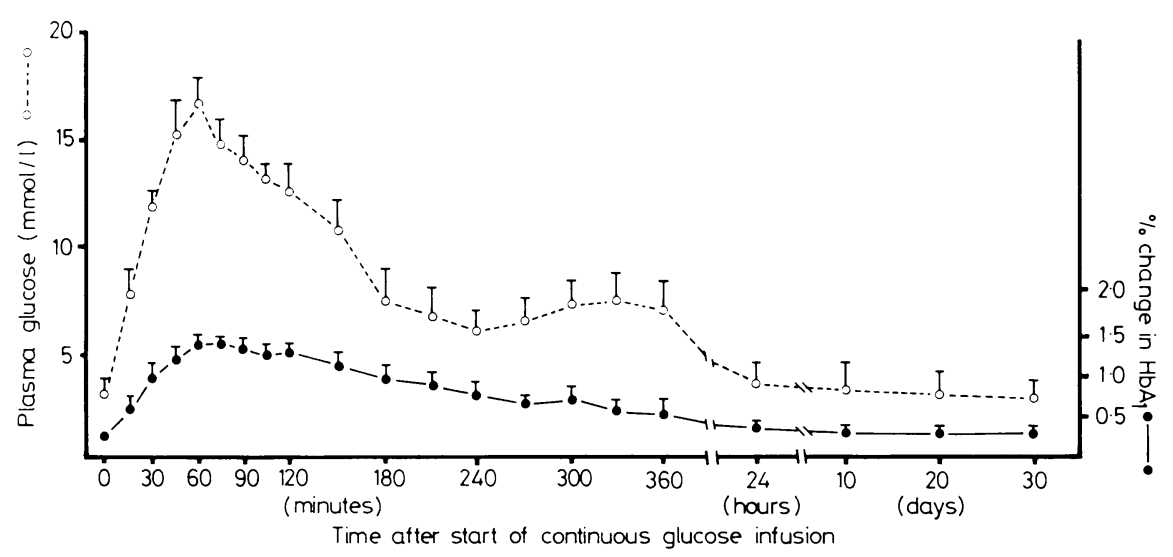

Changes in plasma glucose and $\mathrm{HbA}_{1}$ during and after continuous glucose infusion of $1.0 \mathrm{~g} / \mathrm{kg} \mathrm{h}$ in 10 volunteers (means $\mathrm{SEM}$ ).

Conversion: SI to traditional units-Glucose $1 \mathrm{mmol} / 1 \approx 18 \mathrm{mg} / 100 \mathrm{ml}$.

of glycosylated haemoglobins were measured with a Beckman glucose analyser and the microcolumn technique (Quick-Sep, Isolab) at 15-minute intervals for two hours, at 30-minute intervals for four hours, and one, 10, 20, and 30 days later. Serum glucose rose to a mean level of $16 \cdot 6 \pm 1 \cdot 4$ $\mathrm{mmol} / 1(299 \div 25 \cdot 2 \mathrm{mg} / 100 \mathrm{ml})$ at 60 minutes. $\mathrm{HbA}_{1}$ values increased by $1.3+0.12 \%$, the increase slowly being reduced until it was $0.51+0.10 \%$ after six hours. The coefficient of correlation ( $r$ ) between the change in glucose and the change in $\mathrm{HbA}_{1}$ was found to be $0.89(\mathrm{p}<0.001)$. Twentyfour hours later the $\mathrm{HbA}_{1}$ levels had reached the preinfusion values. After 10, 20, and 30 days no significant change in serum glucose or in $\mathrm{HbA}_{1}$ could be observed (figure).

Several recent in vivo studies have suggested that short-term fluctuations of $\mathrm{HbA}_{1}$ have to be considered as formation and degradation of the reversible part of the haemoglobin-glucose compound (Schiff base, aldimine). ${ }^{2}$ In vitro studies with radioactively labelled $\mathrm{D}$-glucose have shown that the influx of glucose into the erythrocytes across the cell membrane is not a limiting factor for the synthesis of glycohaemoglobin. Equilibrium between intracellular and extracellular glucose concentration is achieved within 15 seconds. ${ }^{3}$ Dissociation of the glucose-haemoglobin compound is an exothermic reaction, also taking place within minutes after removal of free glucose from the red cell. ${ }^{4}$ Thus one would expect an elevation of the unstable form of $\mathrm{HbA}_{1}$ shortly after induction of hyperglycaemia and a decrease of $\mathrm{HbA}_{1}$ after normalisation of serum glucose if time is too short to produce the irreversible ketoamine linkage. Our results clearly indicate that six hours of severe hyperglycaemia in healthy subjects are not sufficient to cause production of stable glycohaemoglobins.

It remains unclear why $\mathrm{Dr}$ Scobie and others did not find an elevation of $\mathrm{HbA}_{1}$ during an oral glucose tolerance test as has already been demonstrated by others. ${ }^{5}{ }^{6}$ Most likely they did not achieve serum glucose levels high enough to result in a measurable effect on $\mathrm{HbA}_{1}$ formation. Since aldimine linkage between glucose and haemoglobin is supposed to be the initial step of condensation, an increase of stable $\mathrm{HbA}_{1}$ 10-30 days after the glucose tolerance test without short-term changes seems hard to explain. Unfortunately the authors did not comment in their paper on the problem of increased glycosylation of haemoglobin in the absence of hyperglycaemia.

F-D GoEBEL H FUESSI

University of Münich Medical Polyclinic,
Münich, West Germany

${ }^{1}$ Goldstein DE, Peth SB, England JD, Hess RL Da Costa J. Diabetes 1980;29:623-8.
${ }^{2}$ Svendsen PA, Christiansen JS, Søegaard U, Welinder BS, Nerup J. Diabetologia 1980;19:130-6.
Sprandel U, Hubbard AR, Chalmers RA. Biochem
Biophys Res Comm 1979;91:79-85. cells. In: Ellory JC, Lew VL, eds. London: cells. In: Ellory JC, Lew

Goebel FD, Fuessl H, Kolmar C, Dörfler H. Schauder P, Hintz W. Disch Med Wochenschr 1981;
106:262-6.

***We sent this letter to the authors, and Dr Scobie replies below.-ED, $B M \mathcal{H}$.

SIR,-I am most interested in the comments of Professor Goebel and Dr Fuessl and the results of the glycosylated haemoglobin estimations they obtained following glucose infusion. Interestingly, they were unable to confirm our findings of significant elevation of $\mathrm{HbA}_{1}$ at days 10,20 , and 30 following a period of hyperglycaemia despite having achieved higher plasma glucose levels by glucose infusion. At this stage I can offer no explanation for this discrepancy, nor can I propose an explanation of our findings based on current concepts of glycosylation of haemoglobin. However, we do believe our results to be valid and because of the timing of entry of the subjects into the study the effects of between-batch assay variation should have been cancelled out. Results similar to ours were obtained by the French workers mentioned in our text. ${ }^{1}$

As we stated, I am sure that the degree of hyperglycaemia we achieved during the oral glucose tolerance test in normal subjects was insufficient to produce a significant increase in the unstable Schiff base or aldimine fraction of $\mathrm{HbA}_{1}$.

To clarify this issue further we intend to repeat the experiment but to include a control group who do not have any oral glucose.

In response to Dr S G Welch's comments of 21 November ( $p$ 1403) on our paper (3 October, p 877), we are, of course, only too aware of the quality control problems and between-batch coefficients of variation of ionexchange procedures for measuring glycosylated haemoglobin. From his own method of analysis of our data he implies that all subjects entered the study at the same time and that $\mathrm{HbA}_{1}$ was measured at each stage synchronously. This was not so. In any one batch the $\mathrm{HbA}_{1}$ at day 60 , for example, of some subjects and the $\mathrm{HbA}_{1}$ at day 10 of other subjects may be measured. Thus effects due to between-batch variation would cancel out and
4 Naftalin RJ, Homan GD. Membrane transport in red Diabetologia 1980;19:277 (abstract) this is not the explanation for the statistically significant increase in $\mathrm{HbA}_{1}$ found after a period of minor hyperglycaemia in our study.

I did state in the text, and reiterate, that I do not think that the recorded rise in $\mathrm{HbA}_{1}$ was due to the presence of Schiff base fraction -it occurred far too late after the period of hyperglycaemia.

Finally, I should like to emphasise that our results made us wonder about the importance of marginal increases in $\mathrm{HbA}_{1}$ in two situations only-namely, tightly controlled insulindependent diabetes with virtual normoglycaemia and very mild maturity-onset diabetes, where it appears that a transient mild period of hyperglycaemia might lead to an increase in $\mathrm{HbA}_{1}$ of almost $1 \%$ of total haemoglobin. In no way do we suggest the general abandonment of this valuable test.

Department of Medicine, St Thomas's Hospital Medical School,
London SEl 7EH

${ }^{1}$ Maquart FX, Poynard JP, Borel JP, Leutenegger M.
Lancet 1978;ii:431-2.

I N SCOBIE

\section{Consultants and their future}

SIR,-Readers of the Short Report, like experts on the Holy Bible, appear to read different meanings into the same paragraphs. As a consultant I knew the proposals would lessen the skill of the consultant's job; while junior doctors' leaders saw salvation for the exploited junior doctor. Now that the Government response has been published the intent is clear, and I hope that two opposing interpretations will not again emerge.

My previous letter (9 January, p 120) dwelt only on the dangers as seen by a consultant, and I could have echoed Dr Michael Rees's praise (23 January, p 276) of some of the Short Report's recommendations such as those relating to organised training programmes, and gearing these to permanent posts, and to better manpower planning. Dr Douglas Gentleman (30 January, p 350) is right that junior posts ought to be deleted when they no longer merit recognition for training purposes; but my criticisms of the report are even more cogent now we know that the government response supports those very recommendations that will, in my opinion, eventually ruin the quality of service to the public provided by hospital doctors.

The response, paragraph 59, says: "To double the number of consultants over the next 15 years and to change the consultant:junior ratio from $1: 1.8$ to $1.8: 1$ would require only about 7000 extra doctors (about 13000 extra consultants but 6000 fewer juniors)." Paragraph 11 accepts that medical school entry will remain at 3859 per annum, necessitating about 3600 preregistration posts, so that at least 7200 senior house officer posts will be needed for mandatory postregistration training, leaving just 7200 posts for registrars-the current number of 24000 junior posts less 6000 7200 and 3600 . Paragraph 24 points out that more senior registrar posts will be needed to provide the extra consultants, and if this figure is between $5000-6000$ it must mean that the current 6955 registrar posts will almost disappear. Even the 18000 junior doctor posts produce a ratio to consultants of $1: 1.4$ and not the $1: 1.8$ sought by Government.

Thus my figure of 4000 SHOs competing for 700 registrar posts is not too far from the Government's intention. That they will mostly be in teaching hospitals might follow from paragraph 4, which discusses the decrease in junior staff: "Other qualifications will relate to the ability of the hospital to provide training facilities of adequate quality."

There are few comments on the change in the consultant role but they are significant. Paragraph 